\title{
Global Sustainable Development Agenda: An Implication for Conservation Challenges in Cross River State, Nigeria
}

\author{
Oliver Okey Oji Enuoh ${ }^{1} \&$ Francis E. Bisong ${ }^{2}$ \\ ${ }^{1}$ Tropical Ecological Consult, Abuja, Nigeria \\ ${ }^{2}$ Department of Geography and Environmental Science, University of Calabar, Nigeria \\ Correspondence: Francis E. Bisong, Department of Geography and Environmental Science, University of \\ Calabar, Nigeria. Tel: 234-80-3338-0315. E-Mail: febisong@yahoo.com
}

\author{
Received: May 8, 2014 Accepted: May 26, 2014 Online Published: July 31, 2014 \\ doi:10.5539/jsd.v7n4p211 URL: http://dx.doi.org/10.5539/jsd.v7n4p211
}

\begin{abstract}
The pristine rainforest of Cross River State of Nigeria is ecologically a region of species endemism and one of the 25 biodiversity hotspots in the world. Globally, there has been a drive for sustainability of these valuable ecosystems. The world Commission on Environment and Development articulates this drive and offers clarifications on the instruments to achieve the goals of sustainable development. However, in many countries such as Nigeria and other African countries, the challenges of achieving the global goal of sustainable development are enormous, given the urge for economic and infrastructural development, and the challenging needs of a burgeoning human population. Natural resources conservation in the above circumstances remain an uphill task. In the developed world, advancement in technology and industrial development also poses a serious problem to the global sustainability agenda. From the Nigerian perspective, with Cross River State harboring more than 50 percent of the remaining pristine rainforest, the challenges to sustainable development include inter alia ineffective implementation of international environmental treaties, high rates of deforestation, biodiversity loss, weak institutions, non-resettlement of enclave communities of parks, and lack of commitment on the part of stakeholders. This paper therefore recommends that forest ecological restoration, biodiversity conservation in parks and protected areas, and industrial strengthening should be pursued as core strategies of sustainable development in Nigeria.
\end{abstract}

Keywords: sustainable development, conservation, challenges, biodiversity loss

\section{Introduction}

The paper argues that large scale environmental shocks in the context of limited capacity (like that of Cross River State of Nigeria), make global sustainable development goals poorly attainable. In such a context, global sustainable development goals can only be accomplished if government, the people, and the international community come together with the required capacity to articulate and implement an action agenda.

The 1995 Random House Webster's College Dictionary defines environment as: "the aggregate of surrounding things, conditions, or influences; surroundings, milieu; the air, water, minerals, organisms and all other external factors surrounding and affecting a given organism at any time; the social and cultural forces that shape the life of a person or population." Common and Stagl (2005: 22) maintain that by environment "we mean Planet Earth. It is one of nine Planets in the solar system, and as far as we know, the only one that supports life." Implicit in the above explanation are other fundamental questions that human generations have been asking and will continue to ask: are there other planets with life supporting systems apart from the earth? What will happen if the life support system of planet Earth becomes obscured one day? Common and Stagl (2005: 22) stress that the Earth functions as a living system - "a set of components that interact with each other" to support life. Human environmental interactions and impacts on different components of the Earth must therefore not undermine their capacity to support life.

Across continents, nations, and cultures, environmental issues and problems are not only common, but dominate their development agenda. Environment is the sector with the highest number of UN or multilateral agencies e.g. the United Nations Environment Programme (UNEP), the United Nations Convention on Biological Diversity (UNCBD), the United Nations Framework Convention on Climate Change (UNFCCC), the United Nations 
Convention on International Trade in Endangered Species (UNCITES), the Global Environment Facility (GEF), and environmental issues and activities are mainstreamed into the development agenda of international establishments like the United Nations Development Programme (UNDP), the United Nations Industrial Organization UNIDO), the World Bank, the United Nations Food and Agriculture Organization (FAO), and bilateral organizations like USAID, DFID, GTZ, JTC, NORAD, etc. In the United States of America alone, there are over one million NGOs working on different environmental matters within and globally. There is hardly any national Government in the world without a department handling environmental matters. Thus it is pertinent to consider the following issues:

1) Why are environmental matters still persistent despite global effort on sustainable development?

2) How effective are national and local institutions in addressing the issues of global sustainable development?

3) Are all stakeholders of sustainable development in support of the goals and vision of conservation?

4) Are there other challenges facing conservation?

5) Are there solutions to the challenges?

\subsection{Environmentally Sustainable Development: The Global Background}

The emergence of the concept of sustainable development in global affairs, in the second half of the $20^{\text {th }}$ century, is underpinned by a combination of political, economic, and social transformations amongst world nations, which culminated in global environmental problems, the search for solutions, and the UN establishment of the World Commission on Environment and Development in 1987. It may be insightful to offer some clarification or further information on what manner of political, economic, and social transformations amongst world nations culminated in the exacerbation of global environmental problems.

Politically, the advent of European colonialism in the $18^{\text {th }}$ and $19^{\text {th }}$ centuries, and subsequent granting of independence to all former colonies, resulted in the emergence of many nation states around the world. In Nigeria like other countries, new national Governments emerged with budgetary financial pressures to provide development services at national, provincial, and district levels. New towns and cities emerged as national, provincial and district capitals, with limitless demands for infrastructural development. Programmes for rural development which resulted in environmental devastation were ubiquitous. Pressure on the exploitation of natural resources as the main source of Government revenue, to increase GDP per capita, and economic growth was typical of most nations around the world. Governments became involved in timber logging, establishment of agricultural plantations, mining of minerals, investment in fishing activities, and the establishment of agro-allied industries, all of which had serious (but ignored) environmental impacts.

Economically, capitalism and the industrial revolution in Europe, in the $18^{\text {th }}$ century, opened a floodgate of inventions and improved technology in different sectors of the economy. Examples include saw mills, chainsaws, and wood factories (in the forestry sector); earth-moving equipments like bulldozers, excavators, graders, etc (in the transport sector);fossil fuel-dependent cars and airplanes (also in the transport sector); assorted machines and tools for agricultural mechanization; commercial fishing with trawlers and chemicals; hunting with guns, rifles, and ammunitions; assorted tools and machinery for solid minerals mining; and drilling of oil (including deep sea drilling) with persistent problems of gas faring and oil spills. All of the above technologies have high and unintended environmental consequences which became clear with time.

Chapin III et al. (2002: 13) observe that

"Since the Industrial Revolution, the magnitude of human impacts on the environment has been so great and so distinct from that of other organisms that the modern effects of human activities warrant particular attention. The cumulative impacts of human activities extend well beyond an individual ecosystem and affect state factors such as climate, through changes in atmospheric composition, and biota, and through the introduction and extinction of species. The large magnitude of these effects blurs the distinction between independent state factors and interactive controls at regional and global scales. Human activities are causing major changes in the structure and functioning of all ecosystems, resulting in novel conditions that lead to new types of ecosystems."

Socially, world human population has been rising over the years (now 7.2 billion), while that of other biological species have been declining steadily. The number of threatened, endangered and extinct biological species continue to rise across the world. IUCN (the World Conservation Union) currently publishes on their website a 
red list of endangered species (see http://www.iucn.redlist.html). To buttress this fact, Robert Malthus had warned that the industrial revolution and unbridled human materialism would culminate in steady rise in human population and depletion of environmental resources to satisfy the needs of an ever increasing human population (Leveque \&Mounolou, 2003).

The second half of the $20^{\text {th }}$ century witnessed the explosion of global environmental problems such as climate change, tropical deforestation, land degradation, and biodiversity loss. Leveque and Mounolou (2003) observe that several scientists came up with research findings that drew global attention to the causes of Ozone layer depletion in the atmosphere, and the adverse consequences of global warming (e.g. rising temperatures, melting of glaciers, sea level rise and flooding of coastal cities, drought, land degradation and food scarcity, etc). All emergent global environmental problems of the $20^{\text {th }}$ century were linked by several scientists to destructive human activities (Chapin III et al. 2002; Leveque \&Mounolou, 2003; Sodhi\& Ehrlich, 2011). Leveque and Mounolou (2003) further maintain that in the 1970s, scientific discourse on nature protection was rampant and effectively amplified by international environmental organizations like the World Conservation Union (IUCN), World Wildlife Fund for nature conservation (WWF), and the World Resources Institute (WRI).

On the strength of the foregoing information, the United Nations Organization established the World Commission on Environment and Development (WCED) in 1987 to assess global environmental problems and to come up with strategies of addressing them. The Commission, headed by Gro Harlem Brundtland, came up with a global report - Our Common Future, which catalogued comprehensively the causes of the world's environmental problems. The first UN sponsored Earth summit (UN Conference on Environment and Development) was summoned at Rio de Janeiro in 1992. It was at this conference that the term Sustainable Development appeared before world leaders for the first time. As defined by Brundtland in 1987, Sustainable development is development that meets the needs of present generations without compromising the ability of future generations to meet their own needs.

Few international development concepts have attracted so much political, popular and academic attention as that of sustainable development. While politicians are adept at embracing high-sounding objectives - especially when they are so loosely defined as to be consistent with almost any form of action (or inaction) - it is significant that sustainable development now figures as a goal in dozens of national environmental policy statements and in the opening paragraphs of "Agenda 21", the massive shopping list of world actions adopted at the Earth Summit in Rio de Janeiro in June 1992.Agenda 21 states:

In order to meet the challenges of environment and development, States decided to establish a new global partnership. This partnership commits all States to engage in a continuous and constructive dialogue, inspired by the need to achieve a more efficient and equitable world economy, keeping in view the increasing interdependence of the community of nations, and that sustainable development should become a priority item on the agenda of the international community (United Nations Conference on Environment and Development, 1992, para. 2.1).

Natural or biological resources on Earth have economic and ecological values. The global sustainability problem hinges on the fact that all over the world, man is yet to strike a balance between economic and ecological values in the use and management of biological resources. Capitalism and economic exploitation of natural resources to continuously create and accumulate wealth now threatens not only the biophysical foundations of future economic activities (for future generations), but the ecological sustainability of life itself on planet Earth. Some authors (e.g. McKibben, 1999) have raised concerns that life on Earth as we know it may come to an end if destructive environmental practices (for economic purposes) by humans, continue. For instance in Nigeria, FAO (2006) report on Global Forest Resources Assessment ranks Nigeria $4^{\text {th }}$ globally among countries with the highest annual deforestation rate $(3.3 \%)$ and net annual area change $(410,000 \mathrm{Ha})$. This means that global sustainable development agenda in Nigeria need to be modernized alongside other development strategies

Global sustainability principles and practice as reflected in Agenda 21 implied that world nations, communities, and businesses, beginning from the Rio Earth Summit of 1992, would mainstream sustainability measures in all sectors of the economy e.g. agriculture, forestry, fisheries, hunting of wild animals, solid minerals mining, urban development, transportation, energy strategies, waste management / recycling of used products, etc. Sustainable development implies that the biological resources on Earth are meant for economic and ecological purposes for past, present, and future generations. Accordingly, the present generation of humans in all nations should ensure intergenerational equity in the use and distribution of resources. No particular generation is expected or has the right to over-consume or over-exploit the resources of the Earth. No generation must upset the Earth's ecological balance or life support capability, through unsustainable environmental activities. 


\subsection{The Nigerian Context of Sustainable Development}

In the Nigerian context (including Cross River State) national environmental problems such as tropical deforestation (due to logging and slash and burn agriculture), desertification, land degradation, gully erosion, floods, rising temperatures, unsustainable hunting practices, and depletion and extinction of several fauna species, all combine to justify the need to embrace sustainable development. After the Rio Earth Summit of 1992 , some countries adopted the approach of the summit to ensure sustainability. However, the key concerns within the Nigeria and Cross River State context is how to embrace sustainability measures in all sectors of our economy (e.g. agriculture, forestry, fisheries, hunting, mining, transportation, waste management / recycling, urban development, energy mechanisms, etc.). Moreover, lack of political will on the part of Government to respond to environmental challenges constitutes a problem to sustainable development. There are various environmental challenges arising from inappropriate agricultural practices, urbanization, infrastructural expansion, commercial logging, high demand for fuel wood, overgrazing, population pressure on resources, weak institutions and policies, rural poverty, land tenure, etc. (World Bank, 2005).

\section{Methodology}

This study adopts Cross River State as a case study to assess the challenges of Nigeria in guaranteeing global sustainable development agenda. Cross River was chosen purposively on the status of being the Biodiversity hotspot of Nigeria - harboring more than 50 percent of the remaining rainforest. Core Communities within the protected areas were purposively selected for their perspective. Data, mostly from secondary sources were used for this study. However, data were also generated from primary sources. Desk review was carried out to assess the various global treaty and conventions geared toward sustainable development and national laws in Nigeria in tandem with the goals of global sustainable development as well as the challenges in implementing the laws. Moreover, Participatory approach using focused group discussion, key informant interviews and stakeholders survey were used to elicit information on the implementation of conservation laws, the community perspectives on conservation as well as governance issues in resource use and control and their challenges.

\section{The Challenges in Nigeria: Perspective from Cross River}

A. The first issue is that Cross River State belongs to a wider national context in Nigeria where our leaders sign international environmental treaties and conventions without taking steps to ensure effective stakeholders implementation (e.g. Government, communities, private sector, etc.) The list of international environmental treaties and convention to which Nigeria is a signatory is presented in table 1. 
Table 1. International environmental treaty and conventions to which Nigeria is a signatory

\begin{tabular}{|c|c|c|c|c|c|}
\hline $\mathrm{S} / \mathrm{No}$ & Description & Signature & Ratification & Depository & \\
\hline 1 & $\begin{array}{l}\text { Convention concerning } \\
\text { the Protection of the } \\
\text { World Cultural and } \\
\text { Natural Heritage }\end{array}$ & $16 / 11 / 72$ & 1974 & $\begin{array}{l}\text { UNESCO, } \\
\text { Paris. }\end{array}$ & $\begin{array}{l}\text { http://www.waado.org/environment/Environmental } \\
\text { Treaties/Nig Environmental Treaties }\end{array}$ \\
\hline 2 & $\begin{array}{l}\text { Convention } \\
\text { International Trade on } \\
\text { Endangered Species of } \\
\text { Wild Fauna and Flora } \\
\text { (CITES), } 1973\end{array}$ & $11 / 2 / 74$ & $09 / 05 / 74$ & $\begin{array}{l}\text { Swiss } \text { Ministry } \\
\text { of Foreign } \\
\text { Affairs, Berne }\end{array}$ & http://www.cites.org/eng/disc/parties/ \\
\hline 3 & $\begin{array}{lr}\text { Convention on the } \\
\text { conservation of migratory } \\
\text { species of } r \text { Wild } \\
\begin{array}{l}\text { Animals1979 } \\
\text { Convention,1979 }\end{array}\end{array}$ & 1987 & - & $\begin{array}{l}\text { Foreign Office } \\
\text { of the Federal } \\
\text { Republic of } \\
\text { Germany }\end{array}$ & \\
\hline 4 & $\begin{array}{l}\text { Convention on the Law } \\
\text { of the sea, } 1982\end{array}$ & $10 / 12 / 82$ & 1986 & & \\
\hline 5 & $\begin{array}{l}\text { Vienna Convention on } \\
\text { the Protection of the } \\
\text { Ozone Layer } 1985\end{array}$ & - & 1988 & $\begin{array}{l}\text { UN Office of } \\
\text { Legal Affairs, } \\
\text { New York }\end{array}$ & \\
\hline 6 & $\begin{array}{l}\text { Montreal Protocol on } \\
\text { Substances that Deplete } \\
\text { the Ozone Layer }\end{array}$ & - & 1988 & & http://ozone.unep-org/Ratification_status/ \\
\hline 7 & $\begin{array}{l}\text { Basel Convention on the } \\
\text { Trans-boundary } \\
\text { Movement of Hazardous } \\
\text { Wastes and their } \\
\text { Disposal, } 1989\end{array}$ & $15 / 3 / 90$ & $13 / 3 / 91$ & $\begin{array}{l}\text { Secretary } \\
\text { General of the } \\
\text { UN }\end{array}$ & http://www.nasel.int/ratification \\
\hline 8 & $\begin{array}{l}\text { United } r \text { Nations } \\
\text { Framework Convention } \\
\text { on Climate Change, } \\
\text { (UNFCCC) } 1992\end{array}$ & $13 / 6 / 92$ & $29 / 08 / 94$ & & $\begin{array}{l}\text { http://unfcc.int/files/essential_background/ } \\
\text { convention/status_of_ratification/application/ } \\
\text { pdf/unfcc_conv_rat_pdf. }\end{array}$ \\
\hline 9 & $\begin{array}{l}\text { Convention on Biological } \\
\text { Diversity, } 1992\end{array}$ & $13 / 06 / 92$ & $29 / 08 / 94$ & $29 / 08 / 94$ & www.cbd.int/convention/parties/list.shtml \\
\hline 10 & $\begin{array}{l}\text { United Nations } \\
\text { Convention to Combat } \\
\text { Desertification(UNCCD), } \\
1994\end{array}$ & 1995 & 08/07/97 & 08/07/97 & www.unccd.int/convention/ratif/ratification.pdf \\
\hline 11 & $\begin{array}{l}\text { African Convention for } \\
\text { the Conservation of } \\
\text { Nature and Natural } \\
\text { Resources, } 1968\end{array}$ & $15 / 09 / 68$ & $02 / 04 / 74$ & $\begin{array}{l}\text { OAU, Addis } \\
\text { Ababa. }\end{array}$ & $\begin{array}{l}\text { www.africa-union.org/root/AU/Documents/Treaties/ } \\
\text { List/AfricaConventiononnatureand naturalresources.pdf }\end{array}$ \\
\hline 12 & $\begin{array}{l}\text { Ramsar Convention on } \\
\text { the Conservation of } \\
\text { Wetlands of International } \\
\text { Importance Especially as } \\
\text { Water Fowl Habitat, } 1971\end{array}$ & $\begin{array}{l}\text { Accession } \\
2 / 10 / 00\end{array}$ & 2005 & UNESCO & $\begin{array}{l}\text { Ramsar Convention } \\
\text { http://erc.unesco.org/cp/convention.asp }\end{array}$ \\
\hline 13 & $\begin{array}{l}\text { The Stockholm } \\
\text { Convention on Persistent } \\
\text { Organic Pollutants, } 2001\end{array}$ & $23 / 05 / 01$ & $24 / 05 / 04$ & & http://www.pops.int/documents/signature/signstatus.htm \\
\hline 14 & $\begin{array}{l}\text { The Cartagena Protocol } \\
\text { on Bio-safety }\end{array}$ & $24 / 05 / 00$ & $30 / 11 / 02$ & & - \\
\hline
\end{tabular}

Source: USAID (2008). 
Following the end of the Second World War in 1945, and the establishment of the United Nations Organization, all important global problems have continued to be tackled through treaties and conventions. Signing environmental treaties and conventions without taking steps towards ensuring stakeholders' implementation or compliance is as bad as not signing at all. Nigeria mostly has these laws in principles and not in practice. There are sometimes conflict within Government ministries, departments and agencies. For instance, the area forestry commission feels should be conserved, ministry of agriculture might see that as a fertile area for farming. That is why it makes sense for Nigeria to take the implementation of environmental treaties and conventions seriously, particularly in the harmonization of Government projects and programmes. Opinion leaders, civil society organizations, social critics, and the academia should demand Nigeria's implementation or compliance with all signed international environmental treaties and conventions. Political leaders and civil servants should be held responsible.

\subsection{Cross River State Environmental Issues and Challenges}

Cross River State is one of the thirty six states of Nigeria that is globally important as a biodiversity hotspot. It is bordered in the north by Benue state of Nigeria, south by the Atlantic Ocean, east by the republic of Cameroon, and west by AkwaIbom and Abia states of Nigeria. The state comprises eighteen local Government areas, with Calabar as state capital. The coastal area has mangrove vegetation, while tropical rainforest occupies the middle and largest part of the state. The northern part of the state is mountainous, and home to the Obudu plateau and ranch resort. Important biodiversity conservation projects in the state include Cross River National Park (CRNP), Afi Mountain Wildlife Sanctuary, Mbe Mountains Gorilla Conservation Project, and several Government forest reserves.

The tropical high forest of Cross River State is Nigeria's biologically richest and last remaining area of pristine rainforest. The biome is part of the lowland Guinean rainforest of West Africa, a global biodiversity hotspot, and a region of species endemism. For example, fauna species in the Boki nation of Cross River State such as the Cross River Gorilla (gorilla gorilla dielhi) is not found anywhere else on planet Earth. In addition certain plant and fauna species in the region are new to science. The state has 17 Government Forest Reserves (created during British colonial rule), totaling $6,101 \mathrm{~km}^{2}$ (table 2).

Table 2. Colonial forest reserves created in Cross River State (1912 - 1960)

\begin{tabular}{llll}
\hline S/No. & Name of Forest Reserve & Year Constituted & Area $\mathbf{K m}^{\mathbf{2}} \mathbf{~}$ \\
\hline 1 & Oban Group Forest Reserve & 1912 & $3,742.55$ \\
2 & Ikrigon Forest Reserve & 1928 & 5.27 \\
3 & Cross River North Forest Reserve & 1930 & 129.50 \\
4 & Cross River South Forest Reserve & 1930 & 349.65 \\
5 & Ukpon River Forest Reserve & 1930 & 313.39 \\
6 & Okwangwo Forest Reserve & 1930 & 468.79 \\
7 & Afi River Forest Reserve & 1930 & 383.32 \\
8 & UmonNdealichi Forest Reserve & 1930 & 108.78 \\
9 & Uwet-Odot Forest Reserve & 1930 & 284.90 \\
10 & Lower Enyong Forest Reserve & 1930 & 28.49 \\
11 & Yache Forest Reserve & 1931 & 15.54 \\
12 & Agoi Forest Reserve & 1940 & 46.62 \\
13 & Boshi Forest Reserve & 1951 & 41.44 \\
14 & Ekinta Forest Reserve & 1953 & 106.78 \\
15 & Boshi Extension Forest Reserve & 1958 & 67.34 \\
16 & Gabu Forest Reserve & 1960 & 5.18 \\
17 & IkomFuelwood Plantation & 1960 & 1.06 \\
& Total & & $\mathbf{6 , 1 0 1 . 2 9}$ \\
\hline
\end{tabular}

Source: Cross River State Forestry Commission 


\subsection{Biodiversity Conservation Projects in Cross River State}

Biodiversity conservation projects in Cross River State comprises (a) Cross River National Park (CRNP) - made up of Oban and Okwangwo divisions (controlled by the Federal Government of Nigeria), (b) Afi Mountain Wildlife Sanctuary (controlled by Cross River State Forestry Commission), (c) Mbe Mountain Wildlife Conservation Project (community-based management), and (d) Pandrillus Primates Conservation Project (captive breeding of drill monkeys) (NGO management). Of the above conservation projects Okwangwo division of CRNP, (b), (c ), and (d) above, are all located in Boki local Government area (LGA) of the state. However the largest area of intact pristine rainforest is in Akamkpa Local Government Area of the state. The bad news is that several fauna species in Cross River State in general and Boki and Akamkpa LGAs in particular, are becoming extremely depleted and some totally extinct due to unsustainable hunting practices (e.g. setting of traps, hunting with dogs, and hunter poisoning of fruits on the forest floor). Examples of extinct fauna species in Cross River State comprise leopard, giant pangolin, bush cow, water chevrotain, and black deer.

\section{B. Deforestation in Forest Reserves}

The second environmental issue is that of deforestation in Cross River State.

Following many years of unsustainable environmental practices in Nigeria and the Cross River State in particular (e.g. slash and burn agriculture, logging, mining, rural roads construction, etc), serious and alarming deforestation is going on in both Government forest reserves and community forests in Cross River State. The level of deforestation in each of the government forest reserves is presented in table 3 . The data shows that five (5) of the reserves have been totally cleared

Table 3. Deforestation in government forest reserves in Cross River State

\begin{tabular}{lllll}
\hline S/No & Name of Forest Reserve & Year Constituted & Area $\left(\mathrm{Km}^{2}\right)$ & $\%$ of deforestation \\
\hline 1 & Afi River Forest Reserve & 1930 & 383.32 & $31 \%$ Cleared \\
2 & Agoi Forest Reserve & 1940 & 46.62 & $33 \%$ Cleared \\
3 & Boshi Forest Reserve & 1951 & 41.44 & $51 \%$ Cleared \\
4 & Boshi Extension F.R. & 1958 & 67.34 & $35 \%$ Cleared \\
5 & Cross River NorthF.R. & 1930 & 129.50 & $61 \%$ Cleared \\
6 & Cross River South F.R. & 1930 & 349.65 & $21 \%$ Cleared \\
7 & Ekinta Forest Reserve & 1953 & 108.78 & $89 \%$ Cleared \\
8 & Gabu & 1960 & 5.18 & $100 \%$ Cleared \\
9 & IkomFuelwood plantation & 1960 & 1.06 & $100 \%$ Cleared \\
10 & Ikrigon Forest Reserve & 1928 & 5.29 & $100 \%$ Cleared \\
11 & Lower Enyong F.R. & 1930 & 28.49 & $100 \%$ Cleared \\
12 & Oban Group F.R. & 1912 & $3,742.55$ & Now CRNP \\
13 & Okwangwo F.R. & 1930 & 468.79 & Now CRNP \\
14 & Ukpon River F.R. & 1930 & 313.39 & $16 \%$ Cleared \\
15 & UmonNdealeachi F.R. & 1930 & 108.78 & $49 \%$ Cleared \\
16 & UwetOdot F.R. & 1930 & 284.90 & $38 \%$ Cleared \\
17 & Yache Forest Reserve & 1931 & 15.54 & $100 \%$ Gmelina \\
& Total & & $6,101.29$ & \\
\hline S & & &
\end{tabular}

Source: Cross River State Forestry Project (ODA-Assisted) - Forest Inventory Report, 1994

Also, Ekinta forest reserve has been reduced by 89 per cent, while Cross River North forest reserve has been reduced by 61 percent. The least cleared forest reserves is the Ukpon River forest reserve which has been cleared by only 16 percent. Oban and Okwangwo reserves have now been converted to National Parks. There is paucity of data on the current situation; however, the recent data shows changes has taken place within the forest of Cross River State (Table 3b). 
Table 3b.Natural forest status of cross river 1991 - 2001 \& 2000-2008

\begin{tabular}{lcccc}
\hline $\begin{array}{c}\text { Assessment } \\
\text { Year }\end{array}$ & $\begin{array}{c}\text { Total forest } \\
\text { cover }\end{array}$ & $\begin{array}{c}\text { \% cover as proportion of state } \\
\text { land }\end{array}$ & $\begin{array}{c}\text { Forest cover } \\
\text { loss }\end{array}$ & $\begin{array}{c}\text { \% of Forest cover } \\
\text { loss }\end{array}$ \\
\hline $1991-2001$ & 7920 & $34.3 \%$ & -1514 & $-12.1 \%$ \\
2001 & 6406 & $30 \%$ & & \\
$2000-2008$ & 7409 & $34.8 \%$ & -1307 & $-17.64 \%$ \\
2008 & 6102 & $28.68 \%$ & & \\
\hline
\end{tabular}

Source: Flasse, 2002 and F. E. Bisong 2011

A look at the vegetation map of Cross River State produced by the British ODA (Overseas Development Administration, now DFID), in 1994 tells the story vividly.

Map of Cross River State showing the level of deforestation:

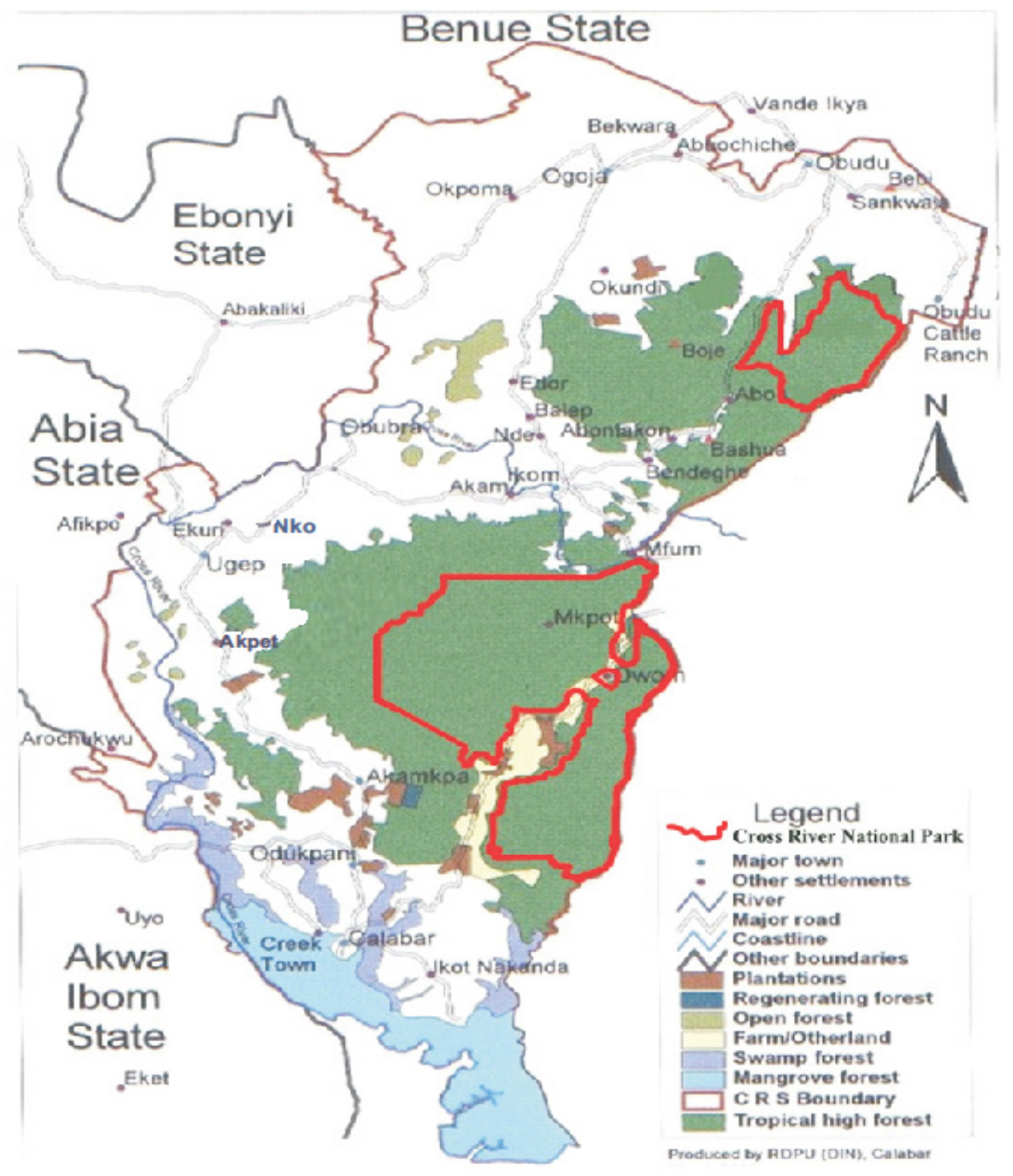

Figure 1. Forest status of cross river

Source: Flasse (2003) 
The above map is now 19 years old, thus further deforestation must have occurred. Stephanie Flasse, one of the DFID consultants (GIS specialist) involved in the second phase of the DFID-assisted Cross River State Forestry Project (1999 - 2002), commented in the DFID final project report (prepared in 2003), that Cross River State forests (under current rate of deforestation) will be exhausted by 2033.This does not mean that green leaves will no longer exist in Cross River State by 2033. The full implication is that merchantable trees (still being harvested in the state), will no longer be there in 2033. Illegal logging, slash and burn agriculture, and rainforest clearance for cocoa, oil palm, and plantain / banana cultivation are ubiquitous in Cross River State.

\section{Biodiversity Loss}

The third and closely consequent environmental issue is rapid biodiversity loss in Cross River State. Biodiversity is the variety and variability among living organisms and the ecological complexes in which they occur (OTA, 1987). The World Bank (2010: 124) defines it as "the variety of all forms of life, including genes, populations, species, and ecosystems." Common and Stagl (2005:521) defines "biodiversity as the diversity of living organisms, the genes that they contain, and the ecosystems in which they exist." Similarly, Noss and Cooperrider (1994:5) maintain that "Biodiversity consists of more than just the variety of species; it involves the full range of species, variation within species, biotic communities, and ecosystems in a dynamic and ever changing process". The biological species or living organisms of any given ecosystem may include some or all of the followings: mammals, birds, reptiles, amphibians, fish, insects, fungi, bacteria, viruses and assorted plant communities (BSP, 1993). The exact number of different biological species that exist on planet Earth is not known yet, but "their number is estimated at somewhere between 7 and 100 million" (Leveque \&Mounolou, 2003:22).

Biodiversity is not distributed evenly across the world (Leveque \&Mounolou, 2003:27). Whereas some areas are rich in biodiversity, some others (indeed a larger percentage of the Earth) are not as rich. $75 \%$ of the Earth's biodiversity is found in the tropics (Tergboh, 2004). Similarly, the World Bank (2010:124) observes that

"two thirds of global biodiversity is in the tropics. A 25 hectare plot in Ecuador was found to have more tree species than exist in all of the United States and Canada, along with more than half the number of mammal and bird species in those two countries."

Conservation International researched and maintain in their findings that there are twenty five biodiversity hotspots in the world (McNeely, et al., 1990). The global distribution of the hotspots is shown below:

\section{The 25 Biodiversity Hotspots}
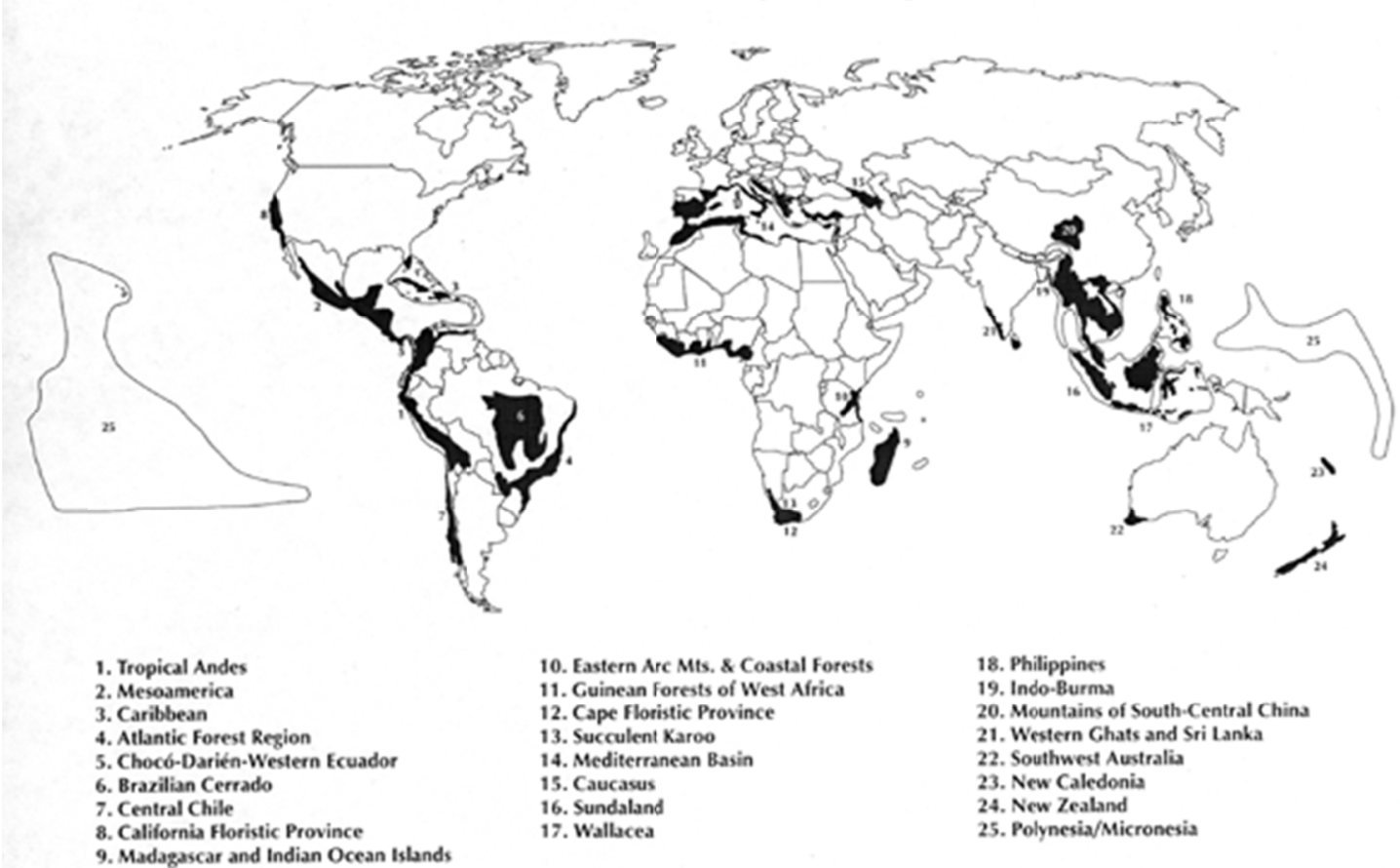

10. Eastern Arc Mts, \& Coastal Forests

11. Guinean forests of West Africa

12. Cape Floristic Province

13. Succulent Karoo

14. Mediterranean Basin

15. Caucasus

16. Sundaland
17. Wallacea
18. Philippines

20. Mountains of South-Central China

21. Western Ghats and Sri Lanka

22. Southwest Australia

23. New Caledoni

24. New Zealand

25. Polynesia/Micronesia

Source: Cincotta, et al. 2000. 
In the above map, the Cross River rainforest is captured in no. 11 (Guinean forests of West Africa). Whereas the stretch of the Guinean forest in other parts of Nigeria and West Africa have been extremely deforested, that of Cross River State being the hotspot in Nigeria is not left out. That is why the Cross River rainforest (straddling Cross River National Park, Government Forest Reserves, and Community Forests) are internationally important.

\section{Weak Institutions}

The fourth and very serious environmental issue is the non-enforcement of wildlife management laws (outside Cross River National Park), by the Cross River State Forestry Commission. Following many years of concentration on logging concessions (logging being a major source of Government revenue up to 1990, (CRFC, 2005)) the Forestry Commission abdicated on their wildlife management responsibilities. No licenses or permits are required for hunting activities in forest communities. There are no periods designated as hunting seasons, and periods when hunting activities are banned. There are no wildlife surveys to inform the public on threatened, endangered, and extinct fauna species, and relevant measures of mitigation. Arrest of hunters appears to be limited to biodiversity conservation project sites only. Animals do not know conservation project territories and boundaries. They can move to buffer zones and other areas. They get killed once they go beyond park or conservation project boundaries. Wildlife management laws are hardly enforced in the rest of Cross River State (outside conservation project sites). In a study of commercial bush-meat hunting practices in west and central Africa, Brown et al. (2008) link fauna species depletion and extinction in the region to the lack of enforcement of wildlife management laws (which seems to exist only on paper).

\section{E. Non-Resettlement of Enclave Communities}

The fifth issue is the non-resettlement of enclave communities (villages located inside CRNP), which continue to fuel commercial bush-meat hunting activities and fauna species depletion and extinction in the park. A national park is supposed to be a territory set aside exclusively for biodiversity conservation, devoid of human encroachment, trespass, or establishment of settlements. Before the formal creation of CRNP in 1991, some villages already existed in the core area of the park. The management plan document of CRNP prepared by WWF/ODNRI in 1989 recommended the resettlement of enclave communities. The resettlement programme was supposed to be carried out within the first seven years of the park's existence. Unfortunately, it is now 22 years since the park was established, and the federal Government is yet to implement the resettlement programme. The Government and people of Cross River State (including national political representatives) appear not to be interested on this very important matter. In 1989, the total number of enclave communities were eight. New settlements have sprang up increasing the number to ten. The Boki communities involved are Okwa I, Okwa II, and Okwangwo. The others are in Oban division of the park.

The non-resettlement of enclave communities is not only fuelling commercial bush-meat hunting activities, but farming, logging, and exploitation of non-timber forest products (NTFPs)in the park. This raises doubt in the minds of Nigerians on the commitment of government to rainforest biodiversity conservation. Forest ownership claims and conflicts between park rangers and the enclave communities have been a persistent source of violent confrontations in Cross River National Park (CRNP). Currently, the affected communities threaten that park staff should not come into their lands. The park constructed patrol posts in some of the enclave villages, but the villagers revolted and demolished them. For the present intensity of commercial bushmeat hunting activities to seize in Cross River National Park, the resettlement of enclave villages is a sine qua non.

\section{F. Lack of Commitment}

The sixth issue is non-commitment of environmental stakeholders in the state (Government, communities, and the private sector) to forest ecological restoration programmes. Ecological restoration is a biodiversity driven forest restoration strategy. Rather than monoculture (reforestation with single exotic tree species like gmelina arborea), ecological restoration is sensitive to local biodiversity and emphasizes the use of indigenous tree species. Ecological restoration is appropriate in Cross River State because of her status as a global biodiversity hotspot. The Forestry Commission has currently raised over 2 million indigenous seedlings in her nursery projects in different parts of the state. The greatest problem impeding full-scale implementation of the forest restoration programme of the Commission is funding.

The Government invested in the forestry sector and made money from wood factories like SEROMWOOD industries (later Calabar Wood), and CALVENPLY (Calabar Veneer and Plywood Industries).The Government made a lot of money from timber concessions granted to companies like Brandler and Rylke Ltd, Kisari Nig. Ltd, Mike's Plant, Hanseatic Ltd, Isulight Ltd, Ikobi Brothers Ltd, Magnificat Ltd, Wempco Ltd, etc. That is how deforestation took place in Government forest reserves. If that is bad news, the worst news is that Government has not been committed to replanting all degraded forest reserves. Checking Nigeria's annual budgets in the last 
ten and twenty years shows that no substantial amount has been committed to rainforest restoration activities. As a people we should be helping the Government get her priorities right. The forest is what makes Cross River State internationally important. If the forest goes, the state loses her global relevance and the world loses an important biodiversity resource.

\section{G. External Control}

The seventh issue is the control of Cross River State economy (including timber markets and natural resources extraction and trade) by non-indigenes or outsiders. The biggest timber market in Cross River State is the Akim Timber Market in Calabar. It is controlled by non-indigenes. We live in a twenty first century world where trade has evolved internationally and nationally. You hear of commodity associations, unions, monopolies and cartels. From the stakeholders' survey and focused group discussion, business moguls and Indigenes of other states are practically controlling businesses in the area, giving the people peanuts for their land and forest. For example numerous business outfits are involved in logging, granite quarries, cement business, agricultural estates or plantations, and forest products extraction. A foreigner once observed that local people play only local politics, with no idea of how to possess the state economically. The Government of Cross River State is currently having a hard time winning the war on deforestation /logging ban because the external controllers of timber trade in the state have a different agenda, and seem to be having their way. The state is yet to see the deforestation problem from this angle, and is thus not coming up with a robust and appropriate response.

As at now, Cross River Gorilla species are caged by surrounding Boki villages. They cannot come out freely to be seen by anybody or tourists, for fear of being killed. As a comparison, a visit to Yankari National Park in Bauchi state of northern Nigeria, will spring a surprise on how baboons feel so free with humans that they troop into tourists guest houses, as they are not afraid of the humans around. They are used to several decades of a culture where humans do not attack them. If the Northerners can allow wildlife to bring them tourism revenue continuously, why not Cross River State? Indeed Yankari has become a prime wildlife tourism destination in Nigeria, partly because other parts of Nigeria are busy killing their own wildlife resources for subsistence income.

Researchers and reviewers of integrated conservation and development projects (ICDP) - in the case of Boki / CRNP (e.g. Oates, 1995; Oates, 1999; and Ite and Adams, 2000), maintain that investments in rural development activities (e.g. roads, bridges, bore holes, health centres, school classroom blocks, rural electrification, micro credit, etc) do not attract positive conservation practices from villagers or benefitting communities (e.g. stopping unsustainable hunting activities and slash and burn agriculture). Between $1991-1994$, WWF undertook several rural development activities in Okwangwo division of CRNP, in the believe that such investments will attract communal cooperation in support of the biodiversity conservation objectives of the park. A review by Ite and Adams (2000) shows that destructive environmental practices amongst benefitting Boki communities (e.g. Abo Mkpang, Kanyang 2, and Bokalum where the study took place) did not change.

The failure of the different tiers of Government in Nigeria to execute rural development programmes in Boki, resulted in local people's expectation that CRNP must perform such roles if conservation is to succeed. In the words of Ite and Adams (2000: 337), "The ICDP approach in Okwangwo division significantly raised community expectations about the nature and pace of socio-economic development in the area, and led to the widespread perception of the national park as a development agency." The communities wanted more development benefits beyond what WWF was able to provide. Oates (1995) reports that the funding of certain livelihood activities in buffer zone communities (e.g. cultivation of oil palm, cocoa, plantain and banana) easily exacerbates deforestation.

The position of some conservationists is that biodiversity conservation in the tropics should not be tied any longer to rural development activities because such investments do not culminate in biodiversity increase in local communities. However some researchers see park support for sustainable livelihoods (not social amenities which Government should provide), as vital if biodiversity conservation is to succeed. A number of international organizations working on bushmeat hunting challenges in parks (e.g. Overseas Development Institute, UK; UK Tropical Forest Forum, and Bushmeat Crisis Taskforce, USA) all agree that livelihood challenges are at the core of reasons accounting for villagers' frequent trespass into the territories of tropical parks.

\section{H. Hazards}

The last environmental issue in Cross River State to be considered in this paper, is the unprecedented and cataclysmic geomorphological event that occurred in Boki on July $12^{\text {th }}, 2012$. On that day a mighty rainfall was not only followed by serious flooding and land-slides, but with crustal movement (similar to what happens in areas that experience earthquakes and volcanic eruptions).Several farmlands and tree crop plantations were 
destroyed, houses in several villages were leveled, roads and bridges were destroyed, wildlife habitats were damaged, canopy walkway was destroyed, new water bodies (rivers and streams) that never existed emerged, and several hectares of forestlands and trees were leveled.

\section{Recommendations for a Best Way Forward}

Forest resources are renewable resources. That is good news. Degraded forestlands can be restored through aggressive forest ecological restoration programmes. Cross River State should take reforestation initiatives and culture seriously. The people of Cross River State were born to meet with forest wealth. They should strive to restore what they have destroyed for the benefit of their future generations and more broadly the world. The UN-REDD programme has come to stay in Cross River State. Those with forest resources will earn a lot of revenue through standing trees and undisturbed forest. Local communities in Cross River State should collaborate with the state Government to win the war against illegal logging, for which an anti-deforestation taskforce has been set.

Several Local Government Areas in Cross River State now have forest without valuable timber species. It is just forest with green vegetation, without Iroko, Ebony, Cedar, Mahogany, Mimosup, Camwood, Black Afara, etc. Illegal logging fetches only subsistence and unsustainable income. Communities without forest in other states are doing better economically. Local communities become poorer when they go cutting down trees. If they are not prepared to plant trees, they should not cut the existing ones. The forest of Cross River State is disappearing at an alarming rate. The state and federal Government should take forest restoration seriously in their yearly budgets.

Cross River State should take biodiversity conservation initiatives (in parks and protected areas) seriously, and find ways of tapping into international funding opportunities that run into billions annually. Efforts should be made to resettle all enclave communities in the Oban and Okwangwo division of CRNP. The affected communities are exacerbating commercial bush meat hunting activities and depletion of the rich biodiversity of Cross River State.

\section{Conclusion}

Following several centuries of industrial revolution, the global practice of capitalism, the pursuit of economic growth amongst nations, and the explosion of human population to 7.2 billion, environmental problems have exploded globally, resulting in the depletion and extinction of biological species. Areas of biodiversity importance are seen ecologically as areas that hold the key to the continuous existence of life on planet Earth. Specifically, human population explosion and economic pressure are exacerbating tropical deforestation, commercial bushmeat hunting activities, logging, commercial agricultural activities, and biodiversity loss) in Cross River State in particular and Nigeria in general. Several flora and fauna species have become extinct in Cross River State due to unsustainable environmental practices. This means that Cross River State is not working towards intergenerational equity in the use and management of natural resources which is a fundamental principle of the concept of sustainable development. That makes development in Cross River State and Nigeria to be environmentally unsustainable. Forest ecological restoration programmes are extremely important.

Cross River State stands the risk of losing their global status as a biodiversity hotspot, if current unsustainable practices in the harvesting of flora and fauna resources continue. Existing conservation establishments in Cross River State (e.g. CRNP, Afi Mountain Wildlife Sanctuary, and the Mbe Mountains Conservation Project) are facing serious anthropogenic challenges that should be addressed. The resettlement of enclave villages in CRNP is yet to take place, 22 years after the park was created. Any level of apathy by government means doom for the entire Cross River State. The time to act is now. In Cross River State there is limited technological capacity in tackling large scale environmental disasters. The state is not viable financially and has done nothing till date to address the 2012 environmental disaster. Thus environmentally sustainable development can only be achieved in Cross River State if the state and federal government of Nigeria, and the international community come together with the requisite capacity to articulate and implement an action agenda.

\section{References}

Bisong F. E. (2010). Nigeria Strategic InvestmentFramework (Nsif) For Sustainable Land Management (Slm): Phase 1, Cross River State (2011 -2020), Draft Report, National Fadama Development Office, Abuja. 
Brown, N.R., Wilkie, D., Bennett, D., Tutin, E., van Toi, C.G., \&Christophersen, T. (2008). Conservation and Use of Wildlife-Based Resources: The Bushmeat Crisis. Secretariat of the Convention on Biological Diversity, Montreal, and Center for International Forestry Research (CIFOR), Bogor. Technical Series no. 33, 50 pages.

Brundtland, G. H. (1987). Address at the Closing Ceremony of the Eight and Final Meeting of the World Commission on Environment and Development at Tokyo, Japan on February $27^{\text {th }} 1987$.

Brundtland, G. H. (1987). Our Common Future - Report of the World Commission on Environment and Development.New York: United Nations Publication.

BSP (Biodiversity Support Program). (1993). African Biodiversity: Foundations for the future. Washington D.C: USAID

BSP (Biodiversity Support Program).(1996). Biodiversity - Facts on the Foundation of Life. Washington D.C: USAID.

Chapin, F. S., Matson, P. A., \& Mooney, H. A. (2002).Principles of Terrestrial Ecosystem Ecology. New York: Springer.

Cincotta, R. P.,Wisnewski, J., \&Engelman, R. (2000).Human population in the biodiversity hotspots.Nature, 404, 990-992.

Common, M. (1995).Sustainability and Policy Limits to Economics. Cambridge: Cambridge University Press.

Common, M., \&Stagl, S. (2005).Ecological Economics: An Introduction. Cambridge: Cambridge University Press.

Constanza, R., d'Arge, R., de Groot, R., Faber, S., Grasso, M., Hannon, B., ...ven en Belty, M. (1997). The value of the world's ecosystem services and natural capital.Nature, 387, 253-260.

Cross River State Community Forestry Project (DFID Assisted). (2003). Final Project Report.

Cross River State Forestry Project (ODA Assisted). (1994). Forest Inventory Report on Cross River State.

Danielson, E. W., \&Denecke, E. J. (1986).Earth Science. New York: Macmillan Publishing company.

Griffo, F. (1995). Talk presented at the Biodiversity and Human Health Conference on April 3rd. Washington DC: The Smithsonian Institution.

Hawtin, Geoffrey. (2008). Securing crop diversity - assuring the future. $25^{\text {th }}$ Annual Ralph Melville Memorial Lecture delivered at the TAA Annual General Meeting held at the Royal Over-Seas League on $28^{\text {th }}$ November 2007. Agriculture for Development: No. 1 Spring 2008.

Ite, U. E., \& Adams, W. (2000). Expectations, Impacts and Attitudes: Conservation and Development in Cross River National Park, Nigeria. J. Int. Dev., 12, 325-342.

IUCN. (2004). Protected Areas Programme: Durban World Parks Congress, 14(2).

IUCN.(2005). Benefits beyond boundaries.Proceedings of the Vth IUCN World Park Congress. Gland, Switzerland and Cambridge, UK: IUCN

Leveque, C., \&Mounolou, J. (2003).Biodiversity.Chichester: John Wiley and Sons Ltd.

McKibben, B. (1999). The End of Nature. Toronto: Anchor Books Doubleday.

McNeely, J., Miller, K. R., Reid, W. V., Mittermeier, R. A., \& Werner, T. B. (1990).Conserving the World's Biological Diversity.Washingto D.C.: IUCN, WRI, CI, WWF, and The World Bank.

Noss, R. F., \&Cooperrider, A. T. (1994).Saving Nature's Legacy - protecting and restoring biodiversity. Washington, D.C.: Island Press.

Oates, J.F. (1995). The dangers of conservation by rural development: A case study from the forests of Nigeria. Oryx, 29, 115-122.

Oates, J.F. (1999). Myth and reality in the rainforest: How conservation strategies are failing in West Africa. Berkeley: University of California Press.

ODNRI / WWF. (1990). Cross River National Park Okwangwo Division: Plan for Developing the Park and its Support Zone. ODNRI: London.

ODNRI/WWF. (1989). Cross River National Park Oban Division: Plan for Developing the Park and its Support Zone. ODNRI: London. 
OTA (Office of Technology Assessment). (1987). Technologies to maintain biological diversity.OTA-F-330. Washington, D.C.: Government Printing Office.

Perring, C., Maler, K., Folke, C., Holling, C. S., \&Jansson, B. (1995).Biodiversity Loss: Economic and Ecological Issues. New York: Cambridge University Press.

Sodhi, N. S., \& Ehrlich, P. (Eds.).(2011). Conservation Biology for All. Oxford: Oxford University Press.

Terborgh, J., \&Schaik, C. V. (2002). Why the world needs parks. In J.Terborgh, C. V.Schaik, \&M. Rao (Eds.), Making Parks Work - Strategies for Preserving Tropical Nature. Washington: Island Press.

UNCED.(1992). Agenda 21. Retrieved April 5, 2013, from http://sustainabledevelopment.un.org/content/do

USAID.(2008). Nigeria Biodiversity and Tropical Forestry Assessment - Maximizing Agricultural Revenue in Key Enterprises for Targeted Sites (Markets).Prepared by Chemonics International Inc.

WCMC (World Conservation Monitoring Centre). (1992). Global Biodiversity: Status of the Earth's Living Resources. Reading, UK: WCMC.

World Band. (2005). Strengthening the Nigerian Forestry Sector to enable Sustainable Forestry and Revenue Generation in Nigeria Productive Forests. Washington

World Bank. (2010). World Development Report 2010: Development and Climate Change.

\section{Copyrights}

Copyright for this articleis retained by the author(s), with first publication rights granted to the journal.

This is an open-access article distributed under the terms and conditions of the CreativeCommons Attribution license (http://creativecommons.org/licenses/by/3.0/). 